\title{
PENERAPAN MODEL PEMBELAJARAN ACCELERATED LEARNING UNTUK MENINGKATKAN KEMAMPUAN LITERASI SAINS PESERTA DIDIK PADA MATERI ZAT DAN WUJUDNYA
}

\author{
Asri Muslimah Syamsi ${ }^{1}$, Chaerul Rochman ${ }^{1,}$, dan Heni Rusnayati ${ }^{2}$ \\ 1. 1Program Studi Pendidikan Fisika, Jurusan Pendidikan Matematika dan Ilmu \\ Pengetahuan Alam Fakultas Tarbiyah dan Keguruan Universitas Islam Negeri Sunan \\ Gunung Djati Bandung. Jalan A.H Nasution o 105. Bandung, Indonesia \\ 2. Program Studi Pendidikan Fisika, Jurusan Pendidikan Fisika, Fakultas Matematika \\ dan Ilmu Pengetahuan Alam, Universitas Pendidikan Indonesia
}

Email: chaerulrochman99@uinsgd.ac.id

\begin{abstract}
ABSTRAK
Tujuan penelitian ini untuk mengetahui keterlaksanaan proses pembelajaran dan peningkatan kemampuan literasi sains peserta didik dengan menggunakan model pembelajaran Accelerated Learning pada materi zat dan wujudnya. Metode yang digunakan dalam penelitian ini adalah preexperiment. Penelitian dilakukan di SMP Triyasa Bandung kelas VII-B. Sampel dalam penelitian sebanyak 48 peserta didik yang dipilih dengan menggunakan teknik random sampling. Data keterlaksanaan aktivitas guru dan peserta didik diperoleh melalui lembar observasi, sedangkan data kemampuan literasi sains peserta didik diperoleh melalui tes uraian. Hasil yang diperoleh dalam penelitian ini: (1) keterlaksanaan pembelajaran dengan menggunakan model pembelajaran Accelerated Learning berkategori sangat baik; (2) kemampuan literasi sains peserta didik mengalami peningkatan. Besarnya peningkatan literasi sains semua aspek peserta didik dapat dilihat dari ratarata N-Gain peserta didik sebesar 0,56 berkategori sedang. Dengan demikian terdapat peningkatan kemampuan literasi sains peserta didik melalui model pembelajaran Accelerated Learning pada materi zat dan wujudnya
\end{abstract}

Kata kunci: Accelerated Learning model of learning, Scientific Literacy, substance and its form

\begin{abstract}
The purpose of study is to determine the feasibility of learning processes and increase science literacy skills of learners using 'Accelerated Learning' model of learning on the material substance and its form. The method used in this research is pre-experiment. The study was conducted in Triyasa junior high school Bandung class VII-B. The sample in the study were 48 students who were selected using random sampling techniques. Data keterlaksanaan activity of teacher and students is obtained through observation sheets, while data on the literacy skills of learners is obtained through the test description. The results obtained in this study: (1) feasibility study by using 'Accelerated Learning' 'model of learning' is in very good category; (2) the literacy skills of learners sins increase in gain results. The magnitude of the increase scientific literacy of students can be seen from the average N-Gain learners of 0.56 categorized being. Thus there is increasing scientific literacy capability of learners through the 'Accelerated Learning' model of learning in material substance and its form.
\end{abstract}

Keywords: Accelerated Learning model of learning, Scientific Literacy, substance and its form 


\section{PENDAHULUAN}

Pembelajaran yang bermakna dapat terjadi jika siswa dapat menghubungkan antara pengetahuan yang baru dengan pengetahuan yang telah dimiliki sebelumnya hal ini dapat diperoleh jika siswa memiliki kemampuan literasi sains yang baik. Literasi sains menurut PISA (2015) adalah kemampuan untuk terlibat dengan masalah pengetahuan sains yang berhubungan dengan ide-ide berdasarkan buktibukti dalam rangka memahami ilmu pengetahuan sains juga sebagai warga negara yang reflektif.

Hasil wawancara dan observasi di SMP Triyasa Ujungberung Bandung pada 4 Maret 2015. Data diperoleh peserta didik mengungkapkan bahwa peserta didik masih sulit memahami materi pembelajaran fisika baik teori ataupun penerapannya. Hasil observasi kegiatan pembelajaran di kelas diperoleh gambaran bahwa pada kegiatan awal tahap apersepsi dan motivasi guru masih kurang memicu peserta didik untuk berpikir berdasarkan fenomena kehidupan sehari-hari sehingga peserta didik kurang mampu mengaitkan pengetahuan yang diperoleh dengan fenomena kehidupan seharihari. Hasil wawancara dan observasi ini diperkuat dengan hasil studi pendahuluan pada tanggal 12 Maret 2015 berupa pemberian soal berbasis literasi sains pada materi zat dan wujudnya dengan nilai rata-rata dari dua aspek literasi sains sebesar 44.37. Hal ini dapat disimpulkan kemampuan literasi sains peserta didik masih rendah.

Berdasarkan pemaparan diatas untuk meningkatkan kemampuan literasi sains dapat dilakukan dengan berbagai upaya, untuk meningkatkan kemampuan literasi sains dengan melakukan kegiatan efisien, dimana guru harus merancang pembelajaran yang menyenangkan dan dapat menarik perhatian siswa. Salah satu model pembelajaran yang menyenangkan dan dapat menarik perhatian peserta didik yaitu model accelerated learning.

Beberapa hasil penelitian yang menggunakan model pembelajaran Accelerated
Learning diantaranya: Penerapan model accelerated learning dapat meningkatkan penguasaan konsep pada materi alat indra siswa kelas IV SDN 2 Jatilawang Wonosegoro Boyolali (Parastri, Ngadino \& Dwiji, 2012). Ditandai dengan meningkatnya nilai tes yang dicapai siswa. Menurut penelitian Taufik dan Husna (Taufik \& Husna, 2013) dapat disimpulkan bahwa penerapan model pembelajaran Accelerated Learning dapat meningkatkan hasil belajar siswa pada konsep hukum Newton. Marindasari, Chumdari \& Ragil (2013) menyimpulkan penerapan model Accelerated Learning tipe MASTER memberikan pengaruh yang lebih besar secara signifikan dibandingkan dengan penerapan model pembelajaran langsung terhadap pencapaian nilai-nilai karakter dalam pembelajaran IPA. Hasil belajar siswa yang belajar dengan Model Accelerated Learning berbasis Peta Konsep lebih baik daripada kelompok siswa yang belajar dengan model pembelajaran konvensional (Suardipa \& Suarni, 2013). Selanjutnya menurut Putra (Putra, Dwi., 2014) menyimpulkan terdapat peningkatkan kemampuan komunikasi matematis siswa yang mendapat pembelajaran Accelerated Learning lebih baik dari siswa yang mendapat pembelajaran konvensional.

Berdasarkan latar belakang masalah di atas, maka peneliti akan mengajukan penelitian yang berjudul "Penerapan Model Pembelajaran Accelerated Learning untuk Meningkatkan Kemampuan Literasi Sains Peserta Didik pada Materi Zat dan Wujudnya".

Tujuan dari penelitian ini adalah untuk mengetahui keterlaksanaan model pembelajaran Accelerated Learning dan peningkatan kemampuan literasi sains peserta didik setelah diterapkan model pembelajaran Accelerated Learning pada materi zat dan wujudnya.

\section{METODE PENELITIAN}


Metode yang digunakan dalam penelitian ini pre-eksperimen. Penelitian ini hanya dilakukan pada kelas eksperimen tanpa adanya kelompok pembanding (kelas kontrol). Desain yang digunakan dalam penelitian ini adalah one-group pretest-posttest design. Representasi desain onegroup pretest-posttest seperti dijelaskan dalam Sugiyono (2013). Jenis data yang diambil dari penelitian ini adalah data kualitatif dan kuantitatif yang diuraikan sebagai berikut:

a. Data kualitatif

Data kualitatif berupa data tentang aktifitas guru dan peserta didik dalam setiap tahapan pembelajaran dengan model Accelerated Learning yang diperoleh dari komentar observer pada lembar observasi.

b. Data kuantitatif

Data kuantitatif berupa data peningkatan literasi sains peserta didik pada pembelajaran dengan model Accelarated Learning yang diperoleh melalui tes uraian pada pretest dan posttest dan data persentase keberhasilan penerapan pembelajaran dengan model Accelerated Learning pada pembelajaran IPA melalui penilaian oleh observer.

Populasi yang digunakan dalam penelitian ini yaitu seluruh siswa kelas VII SMP Triyasa Ujungberung tahun ajaran 2015/2016 yang terdiri atas enam kelas. Sampel yang akan dipilih untuk penelitian menggunakan random sampling (Sugiyono, 2013) yaitu satu kelas pada kelas VII B.

\section{HASIL DAN PEMBAHASAN}

\section{Keterlaksanaan Aktivitas Guru dan Peserta didik dengan Model Pembelajaran Accelerated Learning}

Hasil analisis menunjukkan bahwa aktivitas guru dan peserta didik pada pembelajaran menggunakan model pembelajaran Accelerated Learning mengalami peningkatan pada setiap pertemuan. Adapun interpretasi keterlaksanaan aktivitas guru dan peserta didik secara keseluruhan dapat dilihat pada Tabel 2 dibawah ini:

Tabel 2. Rekapitulasi Rata-Rata Keterlaksanaan Aktivias Guru dan Peserta didik pada Seluruh Pertemuan

\begin{tabular}{|c|c|c|c|c|}
\hline \multirow{2}{*}{ Kegiatan } & \multicolumn{3}{|c|}{ Pertemuan \% } & \multirow{2}{*}{$\begin{array}{c}\text { rata- } \\
\text { rata } \\
(\%)\end{array}$} \\
\hline & 1 & 2 & 3 & \\
\hline $\begin{array}{l}\text { membuka } \\
\text { pelajaran }\end{array}$ & 66.70 & 66.70 & 100.00 & 77.80 \\
\hline Mind & 75.00 & 100.00 & 100.00 & 91.67 \\
\hline Acquire & 83.35 & 91.65 & 91.67 & 88.89 \\
\hline $\begin{array}{l}\text { Search } \\
\text { out }\end{array}$ & 75.00 & 100.00 & 100.00 & 91.67 \\
\hline Trigger & 100.00 & 100.00 & 100.00 & 100.00 \\
\hline Exchibit & 58.34 & 75.00 & 91.67 & 75.00 \\
\hline Reflect & 83.35 & 83.35 & 91.65 & 86.12 \\
\hline $\begin{array}{l}\text { menutup } \\
\text { pelajaran }\end{array}$ & 66.70 & 75.00 & 74.99 & 72.23 \\
\hline rata-rata & 76.05 & 84.38 & 93.75 & 85.42 \\
\hline
\end{tabular}

Tabel 2. tersebut menunjukkan bahwa keterlaksanaan aktivitas guru dan peserta didik dengan menggunakan model pembelajaran Accelerated Learning mengalami peningkatan pada setiap pertemuannya dan termasuk ke dalam kategori sangat baik dengan nilai rata-rata seluruh pertemuan sebesar $85.42 \%$.

Tahap mind yang di dalamnya berisi aktivitas yang bertujuan untuk memotivasi untuk menumbuhkan rasa ingintahu peserta didik sehingga antusias mencari informasi dari materi yang akan dipelajarai. Pada tahap ini peserta didik diberi rangsangan berupa pertanyaan agar lebih siap menerima konsep yang akan dipelajari. Tahap ini berlangsung dengan sangat baik setiap pertemuan.

Tahap acquire yang di dalamnya berisi aktivitas yang bertujuan untuk peserta didik memperoleh informasi mengenai fenomena wujud zat dalam kehidupan sehari-hari. Tahap ini terlaksana dengan sangat baik setiap pertemuan. 
Tahap searching out, tahap ini guru mengajak peserta didik untuk mengaitkan informasi yang diperoleh pada tahap sebelumnya dengan fenomena kehidupan seharihari melalui percobaan sehingga informasi yang diperoleh sebelumnya dapat diinterpretasikan menjadi suatu pengetahuan. Aktivitas guru dan peserta didik pada tahap ini tergolong sangat baik. Ketika pertemuan pertama peserta didik masih belum bisa mengkaitkannya sehingga peserta didik mampu untuk membuat pembelajaran tersebut dan bermakna. Pada pertemuan selanjutnya peserta didik dapat mengaitkan informasi dengan percobaan yang dilakukan.

Tahap trigger, tahap ini peserta didik menjawab pertanyaan yang diberikan guru mengenai informasi dan percobaan yang telah dilakukan sebelumnya. Pada tahap ini keterlaksanaan aktivitas guru dan peserta didik terlaksana dengan kategori sangat baik, seluruh peserta didik menjawab pertanyaan sesuai dengan instruksi guru.

Tahap exchibit, pada tahap ini peserta didik mempresentasikan hasil diskusi tentang percobaan yang dilakukan, kegiatan ini menuntut keaktifan dan keberanian peserta didik. Tahap ini merupakan tahapan dengan tingkat keterlaksanaan rendah dibanding tahapan lain. Hal in karena pada petemuan pertama peserta didik tidak aktif dan belum mampu mengemukakan pendapatnya, sehingga ketika langkah presentasi peserta didik tidak terlaksana. Kemudian pada pertemuan kedua dan ketiga peserta didik mulai aktif mengemukakan pendapat sehingga presentasi dan Tanya jawab terlaksana.

Tahap reflect, pada tahap ini peserta didik memberikan kesimpulan pembelajaran yang telah dilakukan kemudian guru memberikan penguatan terhadap materi yang dipelajari peserta didik dan berusaha menjawab pertanyaan-pertanyaan yang diajukan peserta didik. Setiap pertemuan menunjukkan adanya peningkatan keterlaksanaan aktivitas guru dan peserta didik, dengan keterlaksanaan berkategori sangat baik.

\section{Peningkatan Kemampuan Literasi Sains Peserta Didik}

\section{a. Analisis Skor $\mathbf{N}$-Gain}

Besarnya peningkatan keterampilan generik sains peserta didik berdasarkan nilai pretest dan posttest disajikan pada tabel berikut:

Tabel 3. Skor Pretest, Posttest, dan Normal Gain

\begin{tabular}{ccccc}
\hline & Pretest & Posttest & $N$-Gain & Interpretasi \\
\hline $\begin{array}{c}\text { Rata- } \\
\text { rata } \\
\text { kelas }\end{array}$ & 32.64 & 70,57 & 0.56 & Sedang \\
\hline
\end{tabular}

Berdasarkan Tabel 3. di atas diketahui bahwa peningkatan kemampuan literasi sains peserta didik setelah penerapan model pembelajaran Accelerated Learning pada materi zat dan wujudnya termasuk dalam kategori sedang dengan nilai rata-rata $N$-gain sebesar 0,56 . Peningkatan tersebut dapat digambarkan pada diagram batang berikut.

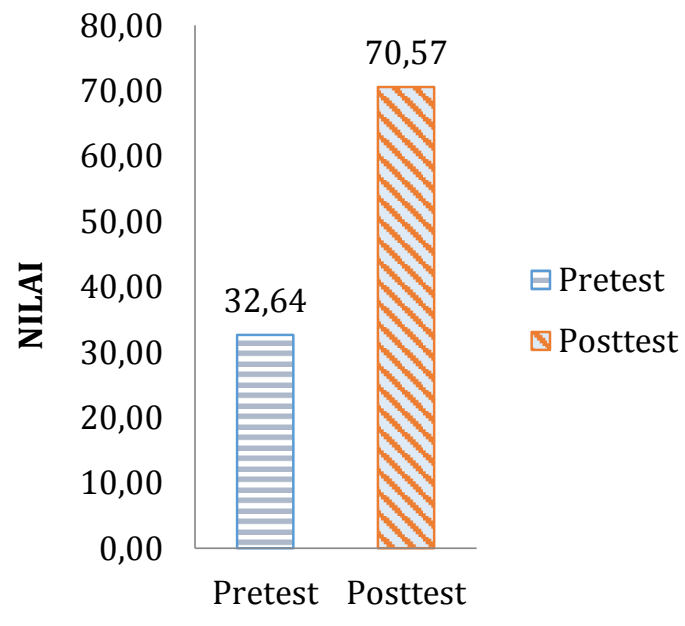

Gambar 1. Nilai Pretest dan Posttest Adapun data peningkatan kemampuan literasi sains pada setiap peserta didik dengan presentase sebagai berikut. 
Tabel 4. Persentase Peningkatan Kemampuan Literasi Sains Peserta Didik pada Setiap Aspek

\begin{tabular}{ccccc}
\hline \multirow{2}{*}{$\begin{array}{c}\text { Aspek } \\
\text { Literasi }\end{array}$} & \multicolumn{2}{c}{ Rata-rata } & \multicolumn{1}{c}{$\begin{array}{c}\text { Inter } \\
\text { pretasi }\end{array}$} \\
\cline { 2 - 5 } & $\begin{array}{c}\text { Pretes } \\
t\end{array}$ & $\begin{array}{c}\text { Post } \\
\text { Test }\end{array}$ & $\begin{array}{c}N- \\
\text { Gain }\end{array}$ & \\
\hline \multirow{2}{*}{ Konten } & 38.02 & 76.56 & 0.63 & Sedang \\
\cline { 2 - 5 } & 40.10 & 72.92 & 0.51 & Sedang \\
\hline \multirow{2}{*}{\begin{tabular}{c} 
Konteks \\
\cline { 2 - 5 }
\end{tabular}} & 41.15 & 77.60 & 0.54 & Sedang \\
\hline $\begin{array}{c}\text { Kompete } \\
\text { nsi }\end{array}$ & 26.04 & 63.02 & 0.49 & Sedang \\
\cline { 2 - 5 } & 25.00 & 63.54 & 0.51 & Sedang \\
\hline $\begin{array}{c}\text { Rata- } \\
\text { rata }\end{array}$ & 33.85 & 70.57 & 0.53 & Sedang \\
\hline
\end{tabular}

Dari tabel 4 diatas memperlihatkan bahwa skor pretest, posttest, dan $\mathrm{N}$-Gain untuk tiap indikator kemampuan literasi sains dari tiga aspek literasi sains yang terdiri dari enam indikator, terdapat satu indikator yang memiliki $\mathrm{N}$-Gain terendah dan tertinggi. Indikator yang memiliki $\mathrm{N}$-Gain terendah yaitu indikator kelima pada aspek kompetensi (Competencies) dengan indikator menerapkan konsep massa jenis dalam kehidupan sehari-hari. Hal tersebut terkait kemampuan peserta didik dalam penerapan massa jenis zat dalam kehidupan sehari-hari. Peserta didik terbiasa menghafal rumus dan menghitung tanpa memahami bagaimana pengaplikasiannya dalam kehidupan sehari-hari, sehingga ketika terdapat pertanyaan yang berkaitan dengan langkah-langkah yang harus dilakukan untuk menngetahui massa jenisnya yang berhubungan dengan penerapannya dalam kehidupan sehari-hari peserta didik merasa kesulitan. $\mathrm{N}$-Gain tetinggi yaitu menganalisis fenomena perubahan wujud suatu zat dalam kehidupan sehari-hari. Hal ini karena ketika pembelajaran peserta didik mengingat hal-hal sederhana dan fenomena tersebut fenomena yang sering peserta didik temui dalam kehidupan sehari-hari.

Analisis jawaban peserta didik berdasarkan kategori jawaban literasi sains mengalami peningkatan dari tingkat nominal menjadi multidimensional, adapun peningkatannya dapat dilihat ada tabel 5 sebagai berikut.

Tabel 5. Hasil Peningkatan Jawaban Kemampuan Literasi Sains Peserta Didik

\begin{tabular}{cc}
\hline Kategori Jawaban Literasi & $\begin{array}{c}\text { Persentase } \\
(\%)\end{array}$ \\
\hline Nominal - Konseptual & 31 \\
\hline Nominal - Multidimensional & 12 \\
\hline Fungsional - Konseptual & 37 \\
\hline Fungsional - & 19 \\
Multidimensional & 100 \\
\hline Jumlah &
\end{tabular}

Dari Tabel 5 diatas, dapat disimpulkan bahwa secara keseluruhan terjadi peningkatan literasi sains, untuk peningkatan literasi sains dari kategori fungsional-konseptual merupakan peningkatan yang paling banyak yaitu sebanyak 18 peserta didik, kemudian yang peningkatan literasi yang paling sedikit yaitu dari kategori nominal-multidimensional sebanyak enam peserta didik.

\section{b. Uji Normalitas}

Uji normalitas dilakukan untuk mengetahui normal atau tidaknya data, maka dilakukan uji normalitas.

Tabel 6. Rekapitulasi Pengujian Normalitas Data Pretest dan Posttest dengan Chi Kuadrat

\begin{tabular}{ccc}
\hline Keterangan & Pretest & Posstest \\
\hline Jumlah (N) & 48 & 48 \\
\hline Standar Deviasi $(\mathrm{N})$ & 6.24 & 16.61 \\
\hline $\begin{array}{c}\text { Derajat Kebebasan } \\
(d k)\end{array}$ & 4 & 4 \\
\hline$x^{2}$ hitung & -114.66 & -199.79 \\
\hline$x^{2}$ tabel & 9.49 & 9.49 \\
\hline
\end{tabular}




\begin{tabular}{ccc}
\hline Hasil & $\boldsymbol{x}^{2}{ }_{\text {hitung }}<$ & $\boldsymbol{x}^{\mathbf{2}}{ }_{\text {hitung }}<$ \\
& $\boldsymbol{x}^{\mathbf{2}}{ }_{\text {tabel }}$ & $\boldsymbol{x}^{\mathbf{2}}{ }_{\text {tabel }}$ \\
\hline Kriteria & Berdistribusi & Berdistribusi \\
& Normal & Normal \\
\hline
\end{tabular}

Berdasarkan tabel 6. di atas, hasil analisis uji normalitas menunjukkan data pretest dan posttest berdistribusi normal, yaitu $\boldsymbol{x}^{2}{ }_{\text {hitung }}<$ $\boldsymbol{x}_{\text {tabel }}^{2}$. Oleh karena itu, maka dilakukan uji hipotesis dengan menggunakan uji $t$.

\section{c. Uji Hipotesis}

Uji hipotesis dilakukan untuk menguji diterima atau ditolaknya hipotesis penelitian yang diajukan. Pada penelitian ini, uji hipotesis dilakukan dengan menggunakan statistik parametris yaitu uji t. Hal ini didasarkan pada hasil uji normalitas yang menunjukkan bahwa data sampel berasal dari populasi yang terdistribusi normal. Rekapitulasi hasil analisisnya dapat dilihat pada tabel berikut:

Tabel. 7. Rekapitulasi Hasil Uji Hipotesis (Uji $t$ )

\begin{tabular}{lc}
\hline \multicolumn{1}{c}{ Keterangan } & Nilai (skor) \\
\hline Jumlah Siswa $(\mathrm{N})$ & 48 \\
\hline $\begin{array}{l}\text { N-Gain maksimum } \\
\left(\mathrm{d}_{\text {maks }}\right)\end{array}$ & 92.00 \\
\hline N-Gain minimum $\left(\mathrm{d}_{\mathrm{min}}\right)$ & 25.00 \\
\hline Jumlah total $N$-Gain $\left(\sum d\right)$ & 1827.00 \\
\hline $\begin{array}{l}\text { Jumlah total } N \text {-Gain } \\
\text { kuadrat }\left(\sum d^{2}\right)\end{array}$ & 75461.00 \\
\hline Derajat kebebasan $(d b)$ & 47 \\
\hline$t_{\text {hitung }}$ & 23,49 \\
\hline$t_{\text {tabel }}$ signifikansi $5 \%$ & 1,678 \\
\hline Hasil & $t_{\text {hitung }}>t_{\text {tabel }} 5 \%$ \\
\hline
\end{tabular}

Berdasarkan Tabel 7 di atas, hasil analisis uji $t$ menunjukan bahwa nilai $t_{\text {hitung }}$ lebih besar dari pada nilai $t_{\text {tabel }}\left(t_{\text {hitung }}>t_{\text {tabel }}\right)$. Dari data tersebut dapat diketahui bahwa $\mathrm{H}_{0}$ di tolak $\mathrm{H}_{\mathrm{a}}$ diterima, hal ini menunjukkan bahwa penerapan model pembelajaran Accelerated Learning dapat meningkatkan kemampuan literasi sains peserta didik kelas VII di SMP Triyasa Bandung pada materi zat dan wujudnya.

\section{KESIMPULAN}

Penelitian telah dilakukan di SMP Triyasa Bandung Kelas VIII-B mengenai penerapan model pembelajaran Accelerated Learning untuk meningkatakan kemampuan literasi sains peserta didik pada materizat dan wujudnya. Keterlaksanaan pembelajaran dengan menggunakan model pembelajaran Accelerated Learning berdasarkan hasil analisis lembar observasi diperoleh bahwa aktivitas guru dan peserta didik selama proses pembelajaran berlangsung sebanyak tiga kali pertemuan mengalami peningkatan pada tiap pertemuan. Rata-rata aktivitas guru terkategori sangat baik, dan rata-rata aktivitas peserta didik terkategori baik.

Dari hasil analisis didapatkan kemampuan literasi sains peserta didik setelah pembelajaran dengan menerapkan model pembelajaran Accelerated Learning mengalami peningkatan. Hal ini dibuktikan dengan hasil pretest dan posttest serta nilai N-Gain peserta didik terkategori sedang. Selain itu, peningkatan kemampuan literasi sains berdasarkan kategori jawaban literasi sains mengalami peningkatan dari kategori nominal menjadi kategori multidimensional.

\section{DAFTAR PUSTAKA}

1. Tatang Koswara, S.Pd., selaku Kepala SMP Triyasa Bandung dan Ibu Aam Kurniasih, S.Pd., selaku guru IPA yang telah memberikan izin penelitian. 
2. Murid-murid kelas VII-B SMP Triyasa Bandung yang senantiasa bersemangat dalam belajar dan memberikan motivasi.

\section{DAFTAR PUSTAKA}

Marindasari, Chumdari \& Ragil. (2013). Pengaruh Penerapan Model Accelerated Learning Tipe Master Terhadap Pencapaian Nilai-Nilai Karakter Dalam Pembelajaran IPA. Jurnal pendidikan: PGSD FKIP Universitas Sebelas Maret Surakarta. Diakses pada: 5 Maret 2015.

Parastri, Ngadino \& Dwiji. (2012). Model Accelerated Learning Meningkatkan Penguasaan Konsep Ipa Materi Alat Indra. Jurnal pendidikan: PGSD FKIP Universitas Sebelas Maret Surakarta. Diakses pada: 3 Maret 2015

Putra, Dwi Jaya. 2014. Penerapan Accelerated Learning dalam Peningkatan Kemampuan Komunikasi Matematis Siswa Sekolah Menengah Pertama. Jurnal Pendidikan: Fakultas Keguruan dan Ilmu Penddikan Universitas Riau Kepulauan Batam. Diakses pada: 6 Maret 2015.

Suardipa, Lasmawan \& Suarni. (2013). Pengaruh Model Pembelajaran Accelerated Learning Berbasis Peta Konsep Terhadap Motivasi Berprestasi dan Hasil Belajar IPS . Jurnal pendidikan: Universitas Pendidikan Ganesha . Diakses pada: 6 Maret 2015.

Sugiyono. (2013). Metode Penelitian Pendekatan Kuantitatif, Kualitatif dan R\&D. Bandung: Alfabeta

Taufik dan Husna. (2013). Penerapan Model Pembelajaran Accelerated Learning Untuk Meningkatkan Hasil Belajar Siswa Kelas X Sma Negeri 1 Dewantara Pada Konsep Hukum Newton. Jurnal Pendidikan
Almuslim, Vol.1 No.1. Diakses pada : 08 April 2015. 